技術学会では従来の性能評価法を JIS ファントムを 中心に見直し1991年 1 月号に揭載予定であり上記の問題 点も考慮しているので参照願いたい.

質問 東村(国立がんセンター) 低コントラスト分解 能測定にスライス㖃の因子を考慮したか.

答（演題142） スライス厚と線量の双方に依存する と考える.

CT 装置の性能評価ファントムは日常点検を目的とし て作られ誰が何度行っても常に同じ結果を得られる測定 法の確立と使用法が簡便である総合的な管理ファントム の登場が望まれる.また各機種の性能比較やデー夕交換 は現有装置の性能上のランク付けができ購入時の参考に なる. 最後に演者諸氏の益々の活躍を期待すると共に会 場で活発な質疑をしていただいた会員の皆様に質疑応答 の全文を揭載できなかった事をおわびする。

\section{CT-3 ファントム（演題番号144～146）}

早川紀和（名古屋大学医学部附属病院分院）

当セッションの演題は, X 線 CT の特定な特性・性能 を解析するためにファントムを試作し，それを使用して 得られた研究成果の報告であった。

演題144は超高速 X線 CT においても藏器の動きによ るモーションアーチファクトが生じる，試作したファン トムによる実験と逆投影法の作図により, 臓器の回転運 動の方向，直線運動の方向および運動速度や画像の重ね 合わせ回数と,アーチファクトの形との関連に付いて明 快に述べていた。このように臟器の動きとモーションア ーチファクトの形の関係が明らかになったので,「この結 果を画像再構成に活かしてアーチファクトをなくせない 功との質問 (座長) に対しては，「現在のところは無理 であり解決法はより高速にしなければなくならない」と の回答であった。今後，ぜひともこの点に関しても研究 することを期待する。

質問 東村（国立がんセンター）急速に变化する造影 剤からのストロボ状のアーチファクトは発生するか.

答 高濃度の造影剂からはメタルアーチファクトのよ うなものは発生するがストロボ状のものとは限らない。

演題145 は高速連続回転型X線 CT のスパイラルスキ ヤンが通常のスキャンと異なる特性を示すスライスの連 続性，スライス厚やモーションアーチファクトを評価す るファントムを開発・実験した結果の報告であった。

3 種類のファントムを開発し，スライス厚やテーブル 移動スピードを変えた時のアーチファクトやスライス厚 の変化などを詳細に検討し，スパイラルスキャンの応用
や有用性を追認した、また，テーブル移動によるアーチ ファクトの消去法も検討し一つの可能性を示唆した。

この報告や今後の研究により, 高速連続スキャンにお いてスライスの連続性に優れているスパイラルスキャン での三次元表示や蔵器の体積測定の精度の向上が期待さ れる。

演題146は X線 CT の非放射性キセノンガスを用いた 局所脳血流測定について，香川医大の桂川（日放技学誌 Vol. 45，No. 11）らも述べるように，同一患者，同一装 置を使用しても種々な因子により測定結果が異なると言 われている，演者らはこの局所脳血流量測定の信頼性を 評価するファントムを試作し，その検討結果を報告した。

このファントムは非放射性キセノンガスの代りに原子 番号の 1 少ないヨード溶液を吸収体として，その濃度の 異なるカプセルの位置き奴吐的に変化させることにより 脳灰白質のキセノン濃度の変化をシュミレートしている. このようなファントムで重要なことはヨード溶液濃度が 経時的に変化しないことである．演者は結果やまとめで 述べてるような点を今後の検討課題とし，より安定した ファントムを開発されることを期待する.

質問 座長 このファントムを使用して施設間の局所 脳血流量測定の比較を行ったか.

答 同一の装置であったが，装置間の誤差は $5 \%$ 程で 有意差はない.

以上がX線 CT 用ファントムのセッションまとめであ る.演者らはそれぞれの目的に応じたファントムを試作 検討した。今後の研究により不偏性あるファントムにし て，他施設でも使用されるようにして欲しい．また，得 られる成果がX線 CT 画像の改善や測定結果の信頼性の 向上に至ることを期待する。

\section{CT-4 CT 值他（演題番号147～151）}

市川秀男（大垣市民病院放射線技術部） CT 画像は断層面の CT 值濃淡分布像であり CT 值は $\mathrm{X}$ 線吸収係数で CT の基本であり根幹になるものである。 CT 装置取扱い者は CT 值の意義を十分理解している必 要があり CT の評価には画像だけではなく CT 值も十分 利用すべきである。

演題147は scan FOV と display FOV について検討し た. 分解能はマトリックスの画素の大きさに比例するも のであり演者も同様に display FOVによって決定され ると報告した。被写体が scan Area 内にある臨床画像で は各測定点の標準偏差は scan FOV おょび display FOVの違いに変化を示さなかったが被写体が Scan 
Area 外にある場合, 画像周辺の高吸収域は scan FOV を大きく設定して display FOV を従来通りにする事で 画像は著しく改善されたと述べた。演者が言うように被 写体がScan Area 外にならないように被写体の横幅を 測ったり, scout view を撮り, 選定し, display FOVも できるだけ撮影範囲（視野）内に目一杯入るように選定 すべきである。

演題148 Reid's base line $-10^{\circ}$ と OM line の側頭骨 CT 像を比較しほぼ同様の画像が得られ耳管においては 描出能が優れまた, 水晶体被曝線量は OM line では水晶 体に13〜15 R（この值を100）で一方 Reid's base line $10^{\circ}$ では $0.28 \sim 0.32 \mathrm{R}$ （2.16）と大幅に減少したと述べ た。耳鼻科領域の検査法はどのようにしていくのか, 宮 下（北海道麻生病院）は70度 coronal 像で特に耳小骨, 上鼓室診断に有用性を認めたと述べている．やはりスク リーニング検查と目的に合わせた精密検査と区別が必要 と思われる.今後より一層の検討を希望する。

演題149 基本フィルタである Fil 008 をS-DOS フ アイルに転送し DCで新しいコンボリウションフィルタ の検討を試み画像に与える影響を述べた。

質問 津坂 (名医短大) 新しいフィルタのチェックを しているか。

答 今回はコンボリューションフィルタの中身を理解 する目的で検討した。会員諸氏もこの種の検討は目的を 明白に持って，十分理解した上で慎重に検討される事を 願う。

演題150 被写体の温度変化をさせながら CT スキャ ンを行い温度が上昇するにしたがって CT 值は下がった 事を述べた．X線は温度上昇によって透過性が上がる事 は知られているが，CTを用いて固体，液体での幅広い CT 值の違いでの加温による実験で化学的解析で電子密 度によると推測された。また臨床応用では生理学的特性 もあり Phantom 策験とは一致しなかったと報告し会員 も非常に興味を持った演題で良い発表で今後さらに一層 検討される事を期待する。

演題151一般的には肺気腫の画像診断は山岸らの Low attenciation area（LAA）の分布を用いられてい る（但し，CTスキャンは浅い吸気状態）（日胸疾会誌 26(2) 1988)

しかし演者は肺気腫を定量化する手法として呼気時の CT 值に簡易的に補正した結果が各種肺気腫機能検査と 良い相関を示した事を発表したが，呼気時では吸気時と 比較すると濃度は上昇し肺血管が不明瞭になったり線維 化に似た像を呈し読影困難になる欠点がある(河野)。ま
た，田中ら（映像情報13：673-678）1981は最大吸気時三 空法 CT で肺気腫の診断ができると報告している.今後 肺気腫の CT 診断方法並びに検查方法はどうするのかお 教光願いたい.最後に発表して頂いた各演者並びに会場 の皆様に深謝する。また今回座長の機会を与えて頂いた 日本放射線技術学会の役員諸氏に深く感謝する.

\section{MR-3 信号処理（演題番号152～154）}

成田廣幸 '名古屋大学医学部附属病院放射線部) MRI 用受信コイルは人体に近づけば近づく程，またコ イルが小さい程，高感度になる。そこで，体表面に近い 組織を撮影したい場合には，サーフェースコイルが使用 されるが，その特性として，撮影可能領域と，領域内で の感度不均一の問題がある. 本セッションはこれらに関 する演題 3 題であった。

演題152は,サーフェースコイルによって収集されたデ 一夕を，一般の画像再構成を行った後に，スムージング 処理を行って輝度分布を作成し，それを使用して濃度補 正を行うと言う事であった。濃度補正のできる範囲をフ アントムにより，サーフェースコイルに垂直な面と平行 な面について示し，ぞちらも感度領域内での濃度の均一 化ができるとしている．深さ方向の補正の臨床例として， 腰部の脂肪腫の術後, 上顎腫晹の $\mathrm{Gd}$ 造影例, 喉頭癌, サ ーフェースコイルと平行な面についての補正の臨床例と して，デュアルコイルを使用した影関節について提示さ れた.この内，上顎腫瘍の $\mathrm{Gd}$ 造影例では，所期の目的を 十分達しているように思われた。喉頭癌の例では，サー フェースコイルからの距離の違い所では, やや SN 比の 低下が見られたようである。この方法は特別な装置を必 要とせず，スキャン時間にも影響を与える事がないため， 有用であるとしている。

演題153は, 微細病変が多く, 高分解能画像が必要であ る脳下垂体部の疾患検査に，頭部用コイルではなく，直 径 $15 \mathrm{~cm}$ の円形サーフェースコイルを使用した場合の有 用性を述べられた，演者らの施設での頭部 MR 画像か ら, 鼻根部から下垂体までの距離を測定し, 統計処理さ れている。この結果と感度領域との関係については取り 立てて言及されなかった。同一ボランティアの磌部用コ イルと表面コイルによる像の比較を提示され, その後臨 床例を提示して優位性を述べられた。

演題154は, マルチビューコイルの導入に際しての, 特 性把握に関する報告であった。脊髄の撮影には，長方形 コイルか，または円形コイルを使用するのが一般的であ るが，撮影可能領域と SN 比に関して一長一短があり， 